\title{
The use of English in Korean TV drama to signal a modern identity
}

\author{
ALEX BARATTA
}

\author{
Switches from Korean to English within Korean TV dramas \\ signal an identity of modernity and power
}

\section{Introduction}

While code-switching is quite a common phenomenon, this paper seeks to investigate a common but underreported use of code-switching. In this paper, I focus on the use of code-switching from Korean to English in South Korean TV dramas. The paper first briefly discusses the literature on the connotations of English language in the Korean media and then proceeds to focus on code-switching using data sampled from three Korean TV dramas. The previous literature (e.g. Lee, 2006; Park, 2006, 2009) which discusses the use of the English language in the Korean media, argues that English carries connotations of modernity and power and this subsequently helps to construct a modern identity for Koreans. However, while Korean music, advertisements and comedies have been discussed with regard to their switches to English, there is little, if any research that focuses on switching to English in Korean TV dramas. The argument put forth in this paper is that switching to English in this context is often a means to reflect an identity of power for the characters and this subsequently might be a reflection of the power and dominance that the English language has in Korean society. In turn, this contributes to conclusions that a modern Korean identity of power derives from being proficient in English.

English is pervasive in Korean society, in terms of its use in Korean commercials, music and TV shows, as well as via the popularity of Hollywood films. Therefore, the use of English in the Korean media is not only a reflection of the dominance of the English language in Korean society, but also a means by which this dominance is propagated. This paper seeks to investigate the connotations of a suggested modern identity that the English language can contribute to within the area of TV dramas.

\section{Literature}

With regard to the rationale for using the English language in the Korean media, Lee (2006: 59) states that 'a modern identity in contemporary South Korea is virtually guaranteed through ... use of English', further regarding English as 'linguistic capital'. The use of English in Korean TV commercials has been investigated by Lee (2006, 2007), as well as its use within modern Korean

ALEX BARATTA is a lecturer
at the University of
Manchester. His research
interests focus on the
relationship between
language and identity,
including developing an
academic identity in one's
writing, while not
compromising the personal


music (Lee, 2007). Flattery (2007) discusses the ways in which a switch to English in Korean pop music (K-POP), for example, can create an identity for the singer which would be unacceptable if the lyrics were sung in Korean (e.g. suggesting promiscuity). Park (2009) further discusses the use of English in TV comedies, offering three suggested purposes for its use. First, the English language is used as an element of the plot 'to serve various humorous purposes' (p. 133), such as Korean characters attempting to use English and failing to communicate clearly. Second, Park states that English switching on Korean TV supports 'the hegemony of global English within Korean society' (p. 134). Finally, Park states that the media serves to disseminate to the public a shared sense of community. This, he argues, is accomplished through making English a plot device and in doing so, reflecting situations which a Korean audience may see as probable (e.g. Koreans' weaknesses in English). Park summarizes his argument by saying that 'media discourse inscribes in people ideologies of who they are, how they relate to the world "outside", and under what terms should their identities be defined' (p. 135). In this case, the Korean community is being partly defined by English language use not through contrived plot devices, but through situations that Koreans can perhaps relate to.

Chung (2011: 9) states that the use of English on Korean TV 'is growing because of the increasingly cosmopolitan story settings'. This can be seen in Korean dramas in which the story is partially set in an English-speaking country and/or involves English-speaking foreigners, itself a growing trend in Korea. It might also be the case that the use of English sends a message to the audience that the Korean characters who use the English language are 'trendy'. This relates to Lee's (2006: 62) research, whereby she argues that English is ideologically portrayed as being part of "the globalizing world' in conjunction with often youthful actors in TV commercials who use English. Park (2006: 247) expands on these notions, discussing the idea that English in Korea has a kind of 'symbolic power', stating that it is associated with 'high quality, internationalism, sophistication and modernity'. Therefore, the use of English language in Korean TV dramas might be based on a desire to communicate such ideals.

\section{Methods}

In order to investigate English code-switches, I collected data from the three Korean TV dramas
Table 1: Korean TV Dramas

\begin{tabular}{lcc} 
Title of & $\begin{array}{c}\text { Number } \\
\text { of } \\
\text { programme }\end{array}$ & $\begin{array}{c}\text { Year of } \\
\text { release }\end{array}$ \\
$\begin{array}{l}\text { You're Beautiful } \\
\text { (미남이시네요) }\end{array}$ & 16 & 2009 \\
$\begin{array}{l}\text { Scent of } \text { a Woman } \\
\text { (여인의 향기) }\end{array}$ & 16 & 2011 \\
Big (빅) & 16 & 2012 \\
\hline
\end{tabular}

introduced in Table 1 (the Korean titles are provided in parentheses). Each episode is approximately an hour in duration.

Prior to writing the current paper, I had lived in Korea for three years (1995-1998) and I continue to visit Korea on an annual basis. From these experiences, I have noticed that English indeed often features prominently in much of the Korean media (including variety shows, dramas, commercials and K-POP). Therefore, the assumption made prior to selecting the three TV dramas was that any given drama may reflect occasional switches to English. In other words, there is not necessarily a specific 'type' of Korean media in which English is favoured (or not). Therefore, the dramas were essentially chosen at random. Dialogues used in all episodes from each drama allowed for sufficient material for discussion within the context of this paper. I watched the dramas on YouTube and the dialogue between characters was spoken in Korean, with English subtitles provided. In the current analysis I rely on the translations from Korean to English provided in these subtitles, with the switch to English presented in italics. A synopsis of each drama is provided below.

You're Beautiful - The story concerns a boy band, A.N.JELL, who unwittingly recruit a female singer posing as a man, Mi Nam. In the end, her identity is revealed and the lead singer of the band, Tae Kyung, has fallen in love with her (as she has with him).

Scent of a Woman - The story focuses on a young woman, Youn Jae, who decides to embark on fulfilling all her wishes, given that she has terminal cancer. She eventually falls in love with the son (Ji Wook) of the president of the company she had worked for, and he with her.

Big - Here we have a teacher, Da Ran, engaged to a doctor, Yoon Jae. One day, Yoon Jae and one of Da Ran's students, Kyung Joon, are involved together in 
a car crash. The result is that Kyung Joon's body is in a coma, but his persona moves into the body of Yoon Jae (a case of body switching, hence a reference to the Tom Hanks' film Big). Complications ensue, to include the return of Jang Mari, who is in love with Kyung Joon and visits him in the hospital where his body is still in a coma (while his persona inhabits someone else's body).

The criteria for the inclusion of Korean-English code-switches within this paper were inclusive, allowing for both code-switching and codemixing. Whereas code-switching involves intersentential communication involving the alternation of two languages between utterances - 'the juxtaposition within the same speech exchange of passages of speech belonging to two different grammatical systems or subsystems' (Gumperz, 1982: 59) - code-mixing is intra-sentential, and involves the alternation of two languages within a given utterance. While there is disagreement regarding the application and/or use of the term 'code-mixing' (Pfaff, 1979; McClaughlin, 1984; Beardsome, 1991), the applications described above are those that this paper adopts. The examples of code-switching that are provided in the current paper represent all those that were used within the three dramas. The following section now presents the analysis, based on the switches to English in each of the three dramas.

\section{Code-switching in You're Beautiful}

The manager of the A.N.JELL band makes notable use of English code-switching, specifically using occasional insertions (Muysken, 2000) of the word jackpot at the end of sentences (as in example 1). This rather esoteric use of the word serves to identify the character's eccentricity, in that he tends to use it merely as an interjection and its use also serves to emphasize the character's enthusiasm for promoting his band and ultimately functions as language play. Therefore, perhaps from the audience's point of view, its use provides humour and largely serves as a 'special conversational effect' (Matras, 2009: 112), as part of the functional continuum of code-switching (Matras, 2009). Likewise, Wells (2011: 69) investigates the code-switches from English to Spanish on a US TV show, and states that English speakers may interpret the switches 'as funny, because it is a mix of sounds they know along with some they are unaccustomed to'.

A typical example of the manager's use of English is provided in example 1. Here, the manager justifies his decision to release a single from Mi Nam. He believes that doing so will build up Mi Nam's popularity, though his decision is met with initial disapproval.

(1) Employee: Mi Nam's popularity is still not high enough, so isn't that out of the question? Manager: Popularity has to be raised strategically. Out of the songs that Tae Kyung has prepared, there's a really good one that's perfect for Mi Nam. After that it's going to be like bam-bam explosion, jackpot!

Li Wei (2005: 382) rightly states that 'codeswitching can be ... described in so many different ways'. While it is beyond the scope of this paper to offer an exhaustive literature review, there are several relevant theories which can help explain the insertion. For example, Myers-Scotton \& Bolonyai (2001) discuss the idea that people's choice to code-switch is primarily based on the speaker's intentions, which is a part of the Rational Choice (RC) Model, with rationality indicating 'the best choice from the speaker's set of possible choices' (Li Wei 2005: 377). The best choice is one that will allow for the most rewards within the context of social interaction. It might, therefore, seem an unusual choice to switch to English as this is the marked form of language, one that could seem 'irrational' from a linguistic perspective. However, Myers-Scotton \& Bolonyai (2001: 2) state that language choice reflects the speaker's 'negotiation of persona', with SchillingEstes (1998: 68-9) further stating that a switch is 'primarily a means whereby speakers alter the images of self which they project for others'.

Based on the perspectives of Myers-Scotton \& Bolonyai (2001) and Schilling-Estes (1998), the insertions could be interpreted as a reflection of the manager's desire to project a certain image of himself; an image perhaps based on socio-cultural influence. More specifically, if English has connotations of power, modernity and status in Korea, then perhaps these qualities might be attributed to the manager, more so given his position of power. While he is a fictional character, we should not forget that the writers of TV dramas arguably reflect trends in the 'real world'. In this case, the high status of English within South Korea is being reflected and the suggested power that comes with the use of the English language. Interestingly, Schilling-Estes (1998) uses the word 'performer' to describe speakers, here an apt metaphor for a character who is arguably 'performing' in terms of 'acting out' a persona for his employees to see. 
A further example of a code-switch involves the use of the imperative right now. The manager of the band issues this imperative in Korean. The fashion coordinator then telephones someone and also relays this information in Korean, only to then end the conversation with a code-switch to English - a very loud right now - after which point she hangs up the phone. This insertion again produces a comical effect, given the fact it is used unexpectedly. Therefore, this defiance of expectations adds emphasis given that English is the marked form. However, one may ask why (from a theoretical point of view) an individual may want to switch to English in this instance.

The answer might be explained by metaphorical code-switching (Gumperz, 1982). In this specific instance, there are arguably important connotations associated with using English. Given the suggested status of the English language within Korean society, a switch to English might suggest authority on the part of the fashion coordinator. This, in turn, provides a reason for delivering her demand in a language of power - a means to emphasize her authority in the first instance as a person entitled to give orders. Also, one may note that we have no knowledge of whether the addressee is proficient in English. Therefore, it could be argued that one of the requirements for codeswitching in the bilingual mode, that both speaker and addressee are bilingual (Grosjean, 2001), may or may not be met. Within the 'real world', there are instances of code switches and insertions that can involve 'situations of superficial or minimal bilingualism' (Matras, 2009: 111), which need not go beyond more than a few words of a second language. However, it is arguably irrelevant if the addressee, or the speaker for that matter, is competent in English. This might suggest that the insertion is used superficially for comical effect and not to communicate semantic content of that message per se. Nonetheless, it is a means to emphasize the imperative the character delivers in order to project an image of authority. Yoon (1996) discusses code-switching in general as a means by which power, authority and prestige are reflected and the switch to English is arguably a means to demonstrate an identity that comprises such factors.

A final switch occurs when the female villain, $\mathrm{He} \mathrm{Yi}$, confronts Mi Nam alone (see example 1).

(2) He Yi: You had a lot of fun hanging out with them, pretending to be a man, huh? What colour do you like from there? Yellow, black or lime?
The reference to colours is actually a reference to the colour of clothing of three male members of the band. Therefore, Mi Nam is really being asked which of the male band members she likes, with $\mathrm{He} \mathrm{Yi}$ jealous that Mi Nam has feelings for a specific band member. The switch to English serves to emphasize the nature of the enquiry, with its marked form essentially forcing Mi Nam to focus more on the content of the question. Gumperz (1982: 144) comments that emphasizing a point and exerting authority are two reasons to code switch and in example 2, these factors are demonstrated.

In summary, the code-switches to English in this drama are used mostly to punctuate the speech of the TV characters by acting as a marked, emphatic form of language. From a theoretical point of view, the switches largely serve to reveal the identity of the characters, or the identity they wish to portray, arguably one of authority and power.

\section{Code-switching in Scent of a Woman}

In this particular TV drama, no instances of English code-switching were used. However, the drama's dialogue does involve a code-switch to Spanish. It occurs on a few occasions, in which a Korean tango teacher uses the phrase uno, dos, tres, cuatro to begin the students' dance routine. Here, the use of Spanish arguably creates a moment of authenticity, given the Argentinean origins of the dance. However, we must look deeper to the specific contextual factors involved within the narrative. First, the dance teacher's day job is that of a hospital orderly and his character in this context is presented as rather bumbling. However, by night he is an accomplished dance teacher. Already we might argue that this represents somewhat of an identity transformation (i.e. 'ordinary worker' by day, 'hero' by night). The character switch also creates humour in that the individual is perhaps unlikely to be associated with such a passionate and intricate dance. To add to the humour, the character, though bald, wears a wig for his role as a dance teacher. This too creates an image of transformation. Therefore, his proficiency in dance and Spanish helps to create a transformed identity, from a bumbler into a 'suave' individual, with power implicit in his identity as a dance teacher.

\section{Code-switching in Big}

An early switch to English occurs when the teacher, Da Ran, meets with Kyung Joon on his first day at 
school (example 3). As Kyung Joon has studied in America, his English is quite proficient.

(3) Kyung Joon: Is it OK for me to follow you this time?

Da Ran: Follow me.

As example 3 involves a switch as part of a conversation and not merely an insertion, we might turn to the work of Auer (1984, 1995, 1998), who, along with Li Wei (1998, 2005), emphasizes the importance of conversation analysis (CA) as a means to interpret code-switching. This approach regards social variables, such as identity, as less relevant to the conversation and does not automatically assume the relevance of such a priori. Instead, CA is concerned with showing how people communicate as part of the social order, in which face-to-face interaction plays a large role. According to Li Wei (2005: 381), this approach does not require 'models of rationality' or 'hidden motives' and Myers-Scotton \& Bolonyai (2001) point out that CA 'downgrades' speaker motivations.

However, we need to consider why there is a switch to English in example 3. Indeed, motivations for speech are 'universally present' (MyersScotton \& Bolonyai 2001: 5) and to not consider these motivations means that it is difficult to make any kind of prediction regarding the occurrence of a code-switch in conversation. Considering the context in which the switch occurs, it is arguably more necessary to speculate on speaker motivations. That is to say, there is one quite important contextual factor involved in example 3, that of the teacher-student relationship in Korea, which very much involves issues of identity. The work of Clyne (1967) is relevant here as it refers to the contextual factors associated with the social setting and how such factors can inspire a switch to another language. The situational switching in a social situation between a teacher and a student in Korea carries implications of power, given the much higher status accorded to teachers in Korea and the 'subordinate' position of students. The sociolinguistic norm in such a situation requires Korean students to communicate with their teachers using a formal style of speech.

Indeed, teachers in Korea occupy a very high position in the social hierarchy and students must defer to them (in the past, a student could not even walk in the teacher's shadow). Based on this, perhaps Da Ran does not wish to be 'outdone' by her student and lose face (in both the theoretical sense and the larger Korean sense), especially by a student who is portrayed as quite insolent. Therefore, Da Ran's switch to the marked language of English might serve to communicate and re-establish her authority in that she too can speak the language which has a high status in Korea.

Later in the scene, Kyung Joon speaks to Da Ran in an informal manner, thus disobeying the Korean honorifics system. Da Ran comments on this, to which Kyung Joon replies in example 4.

(4) Kyung Joon: It's because my Korean is still a bit awkward, sorry.

Da Ran: It seems that you don't know because you're from America, but this is a very famous line in Korea so listen very carefully. I'm a teacher and you're a student! I am a teacher and you're a student, $O K$ ?

Kyung Joon: OK, Gil Da Ran.

Da Ran: Gil Da Ran? Teacher! Teacher! Teacher! Teacher!

Kyung Joon: OK, teacher Gil.

Da Ran's switch to English in example 4 when talking about the teacher-student relationship serves to reinforce the message regarding Kyung Joon's lower status. On a basic level, this switch to English is also a means to ensure that this message is clearly understood, given Kyung Joon's proficiency in the English language. Moreover, there is the need for Kyung Joon to obey the cultural rules of Korean, inherent in the language itself. Therefore, a switch to English helps to further convey the point regarding Kyung Joon's 'place' in Korean society, a contrast to that of the USA. However, on a socio-cultural level, the switch reinforces Da Ran's own social status and identity and, by implication, her 'rank'. By switching to English, she is demonstrating that she is not to be 'outdone' by her student in any way, an unthinkable proposition perhaps in Korea. Therefore, Da Ran is showing that she is capable of standing her linguistic and social ground.

When Da Ran shouts the word teacher four times in example 4, she uses English in the first two cases. Although this switch is perhaps used for comical effect for the audience, from the narrative perspective it emphasizes the cultural conventions. In this case, one's teacher is not a close friend and must be addressed only as teacher. Her switch back to Korean in using the word 'teacher' (sonsengnim) helps to also convey the importance of the cultural context, as teacher is synonymous with respect and seniority in Korea, conveyed by the honorific suffix -nim. Moreover, Da Ran's switch to English relates to Myers-Scotton's (1993) work, in this case by focusing on the unmarked (i.e. conventional) language - Korean 
- and the marked (i.e. unexpected) form, which is English. The point is that a switch to a marked form can be a signal to establish a new set of rights and obligations (RO), with RO sets referring to the abstract social codes involving participants in a given interaction. In this case, the social codes within Korean society are clearly reflected in the honorifics-based language. As Kyung Joon is speaking Korean, but ignoring this crucial aspect of the language, a switch to English by Da Ran is perhaps a strategy to force her student to speak appropriately in Korean. In other words, by using the language that perhaps Kyung Joon wishes to use himself, the message can be communicated that bit more clearly about the need to speak his native language like a native speaker. In doing so, Kyung Joon must also obey the relevant social hierarchy in the process. This would allow for Da Ran's position of power to be respected and in turn, her identity as a teacher (i.e. an identity of power, hence her switch to a language of power).

It might be argued that the switches to English are a necessary plot contrivance based on a character having been schooled in the USA. However, we must again consider the broader social connotations regarding the use of English which would reflect a desire on the producers' part to include English in the storyline. In line with Park (2009), the use of English in this drama works on two levels. First, it is connected to a narrative which reflects a common practice in Korean culture, that of wild geese families, consisting of children who are sent to English-speaking countries in order to improve their English, often going with the mother while the father stays behind in Korea. Second, while the use of English might be regarded as amusing by the viewers, its ultimate purpose is arguably one that goes to the core of modern Korea. The use of a language such as English is a reflection of modernity and power, precisely because that is why it is studied so widely, as a means to be part of the modern world, and the future. Moreover, the fact that the TV characters use this language to also convey rank or power in terms of their social identity is telling.

\section{Conclusion}

The results of the analysis presented within this paper can be summarized as follows. First, regarding the socio-cultural connotations associated with English language in the Korean media, the use of English reflects its high status as a language for which there is indeed a desire for Koreans to learn. Furthermore, there are specific connotations thereby associated with English, such as modernity and power. Furthermore, the switch to English can be a prominent aspect of a drama's narrative, as in the examples from Big, and thus provide the audience with relatable societal situations. Second, while there are many theoretical perspectives on which to base one's analysis of code-switches, this paper has focused particularly on the work of Myers-Scotton (1993). This is because her work focuses on identity, which can be a factor regarding one's motivation to switch as well as one's (perceived) identity being a product of the switch. While CA is greatly relevant to the analysis of code-switching, disregarding the motivations of the speaker for his/her desire to code-switch, means ignoring the issues of identity that might affect code-switching. While discussing motivational factors can be seen as speculative, we can look to the surrounding social context (e.g. the teacher-student relationship in Korea) to provide necessary information, as the social situation is a defining concept regarding the decision to switch. Finally, the use of English in the TV dramas presented in the current paper serves to reflect a variety of factors in relation to the characters who use it, such as a projected identity of authority and power.

\section{References}

Auer, P. 1984. Bilingual Conversation. Amsterdam: John Benjamins.

—. 1995. 'The pragmatics of code-switching: A sequential approach.' In L. Milroy \& P. Muysken (eds), One Speaker, Two Languages: Cross-Disciplinary Perspectives on Code-Switching. Cambridge: Cambridge University Press, pp. 115-36.

-. 1998. Code-Switching in Conversation. London: Routledge.

Beardsome, H. 1991. Bilingualism: Basic Principles. Philadelphia, PA: Multilingual Matters.

Chung, K. 2011. 'Korean English fever in the U.S.: Temporary migrant parents' evolving beliefs about normal parenting practices and children's natural language learning.' Unpublished $\mathrm{PhD}$ thesis. Urbana-Champaign, IL: University of Illinois.

Clyne, M. 1967. Transference and Triggering. The Hague: Nijhoff.

Flattery, B. 2007. 'Language, culture, and pedagogy: An overview of English in South Korea.' Online at $<$ http://homes.chass.utoronto.ca/ cpercy/courses/ eng6365-flattery.htm> (Accessed March 12, 2013).

Grosjean, F. 2001. 'The bilingual's language modes.' In J. Nicol (ed.), One Mind, Two Languages: Bilingual Language Processing. Oxford: Blackwell, pp. 1-22.

Gumperz, J. 1982. Discourse Strategies. Cambridge: Cambridge University Press. 
Lee, J. 2006. 'Linguistic constructions of modernity: English mixing in Korean television commercials.' Language in Society, 35(1), 59-91.

—. 2007. 'I'm the illest fucka.' English Today, 23(2), 54-60.

Li, W. 1998. 'The 'why' and 'how' questions in the analysis of conversational codeswitching.' In P. Auer (ed.), Code-Switching in Conversation: Language, Interaction, and Identity. London: Routledge, pp. 156-76.

—. 2005. "'How can you tell?" Towards a commonsense explanation of conversational code-switching.' Journal of Pragmatics, 37(3), 375-89.

Matras, Y. 2009. Language Contact. Cambridge: Cambridge University Press.

McClaughlin, B. 1984. Second-Language Acquisition in Childhood. Volume 1: Preschool Children. Hillsdale, NJ: Lawrence Erlbaum.

Muysken, P. 2000. Bilingual Speech: A Typology of Code-Mixing. Cambridge: Cambridge University Press.

Myers-Scotton, C. 1993. 'Common and uncommon ground: Social and structural factors in codeswitching.' Language in Society, 22(4), 475-503.
Myers-Scotton, C. \& Bolonyai, A. 2001. 'Calculating speakers: Codeswitching in a rational choice model.' Language in Society, 30(1), 1-28.

Park, H. 2006. 'English as fashion: English mixing in women's fashion magazines.' Unpublished $\mathrm{PhD}$ thesis. Urbana-Champaign, IL: University of Illinois.

Park, J. 2009. The Local Construction of a Global Language: Ideologies of English in South Korea. Berlin: Mouton de Gruyter.

Pfaff, C. 1979. 'Constraints on language mixing: Intrasentential code-switching and borrowing in Spanish/ English.' Language, 55(2), 291-318.

Schilling-Estes, N. 1998. 'Investigating "self-conscious" speech: The performance register in Okracoke English.' Language in Society, 27(1), 53-83.

Wells, M. 2011. 'Codeswitching in the comedy of George Lopez.' Journal of Applied Language Studies, 5(1), 65-76.

Yoon, K. 1996. 'A case study of fluent Korean-English bilingual speakers: Group membership and code choices.' Journal of Pragmatics, 25(3), 395-407.

\section{CAMBRIDGE}

\section{LEADERS IN LANGUAGE AND LINGUISTICS from CAMBRIDGE UNIVERSITY PRESS!}

Conversational

Repair and

Human Understanding

Edited by Makoto Hayashi,

Geoffrey Raymond, and

Jack Sidnell

Studies in Interactional

Sociolinguistics

S95.00: Hb: 978-1-107-00279-1: $394 \mathrm{pp}$

\section{Singapore English}

Structure, Variation and Usage

Jakob R. E. Leimgruber

Studies in English Language

S90.00: Hb: 978-1-107-02730-5: $164 \mathrm{pp}$.

Sociolinguistic

Fieldwork

Natalie Schilling

Key Topics in Sociolinguistics

\$99.00: Hb: 978-0-521-76292-2: 323 pp

S36.99: Pb: 978-0-521-12797-4

Prices subject to change.

\section{Sociolinguistics}

The Study of Speakers' Choices

Second Edition

Florian Coulmas

\$105.00: Hb: 978-1-107-03764-9: 336 pp.

\$42.99: Pb: 978-1-107-67556-8

The Cambridge

Dictionary of Linguistics

Keith Brown and Jim Miller

s99.00: Hb: 978-0-521-76675-3: 450 pp.

The Language of

Life and Death

The Transformation of Experience in Oral Narrative

William Labov

\$85.00: Hb: 978-1-107-03334-4: 256 pp.

S27.99: Pb: 978-1-107-65681-9

\section{Understanding Politeness}

Dániel Z. Kádár and

Michael Haugh

\$99.00: Hb: 978-1-107-03168-5: 320 pp.

S39.99: Pb: 978-1-107-62694-2 